Journal of Advanced Research in Fluid Mechanics and Thermal Sciences

Journal homepage: www.akademiabaru.com/arfmts.html ISSN: 2289-7879

\title{
A Review of Comparative Study on The Effect of Hydroxyl Gas in Internal Combustion Engine (ICE) On Engine Performance and Exhaust Emission
}

\author{
Amir Ridhuan ${ }^{1}$, Shahrul Azmir Osman ${ }^{1,}{ }^{*}$, Mas Fawzi $^{1}$, Ahmad Jais Alimin ${ }^{1}$, Saliza Azlina Osman ${ }^{1}$ \\ 1 Automotive Research Group (ARG), Centre for Energy and Industrial Environment Studies (CEIES), Faculty of Mechanical and Manufacturing \\ Engineering, Universiti Tun Hussein Onn Malaysia, Parit Raja, 86400, Johor, Malaysia
}

\section{ARTICLE INFO ABSTRACT}

Article history:

Received 29 April 2021

Received in revised form 25 July 2021

Accepted 3 August 2021

Available online 17 September 2021

\begin{abstract}
This introductory study comes up with an innovative idea of using Hydroxyl gas as a fuel performance enhancer to reduce the natural sources and the overuse of fossil fuel resulting in increased pollution levels. Many researchers have used HHO gas to analyze gasoline and diesel in internal combustion engines. The main challenges of using $\mathrm{HHO}$ gas in engines have been identified as system complexity, safety, cost, and electrolysis efficiency. This article focuses on different performance reports and the emission characteristics of a compression ignition engine. As opposed to general diesel, this study found that using $\mathrm{HHO}$ gas improved brake power and torque. In all cases, an increase in braking thermal efficiency can be observed. This was due to the presence of hydrogen in $\mathrm{HHO}$ gas with higher calorific value than fossil fuels. At the same time, the fuel consumption unit of the engine was reduced, and the combined impact of hydrogen and oxygen helped to achieve complete combustion and improved the combustion capacity of the fuel when $\mathrm{HHO}$ gas was injected. The addition of $\mathrm{HHO}$ gas also improved the Brake Power (BP), Brake Torque (BT), Brake Specific Fuel Consumption (BSFC), and thermal efficiency while simultaneously reducing $\mathrm{CO}$ and $\mathrm{HC}$ formation. The rise in $\mathrm{CO}_{2}$ emissions represented the completion of combustion. Therefore, the usage of $\mathrm{HHO}$ gas in the Compression Ignition $(\mathrm{Cl})$ engine improved the

engine performance and exhaust emissions.
\end{abstract}

Keywords: performance; Engine emission

\section{Introduction}

The global demand for energy is very high in relation to the supply amount from traditional sources, and the real crisis may occur due to the depletion of fossil fuels and climate changes affected by combustion in engines, producing harmful gases such as Carbon Monoxide (CO), Carbon Dioxide $\left(\mathrm{CO}_{2}\right)$, Nitrogen Oxide (NOx), and Hydrocarbon ( $\left.\mathrm{HC}\right)$. Some of the ill effects of these pollutants are global warming, acid rain, and various health issues [1]. Many researchers have conducted intensive research on alternative fuels in the past few decades and led many studies conducive to improving engines' economy and emission characteristics. Hydrogen is a new renewable energy source with a calorific value of $120 \mathrm{MJ} / \mathrm{kg}$. The energy value is much higher than gasoline, diesel, or CNG gas fuel

\footnotetext{
* Corresponding author.

E-mail address: shahrula@uthm.edu.my
}

https://doi.org/10.37934/arfmts.87.2.116 
$[1,2]$. The electrolysis process is one of the most basic methods to produce HHO gas composed of hydrogen and oxygen [4]. The process is being driven by the movement of electrons, which continuously circulate through an external circuit. They use a pair of wires to connect the electrodes of the Volta battery to the other ends immersed in the salt solution. According to the conductivity of water, hydrogen and oxygen have started to collect at the electrode's edge [5]. Since the reaction generally occurs at constant pressure and temperature, the electronic movement transmits the reaction (current). A practical solution for onboard hydrogen production avoids the storage of heavy pressurized hydrogen tanks [6].

$\mathrm{HHO}$ gas is a colorless and odorless gas. Under atmospheric conditions, the expansion ratio of liquid to gas is 1:848 [7]. Hydrogen consisting of $\mathrm{HHO}$ gas has a higher specific energy density. By mass, it provides three times the energy of other fossil fuels, reflected in its lower calorific value [9]. In comparison to conventional fossil fuels (CNG, gasoline, and diesel) commonly used in the transportation industry, $\mathrm{HHO}$ gas has particular physical and chemical characteristics, as seen in Table 1. Such fuels' engine performance in various engine modes is generally compared to $\mathrm{HHO}$ gas and will be addressed in the testing process. One of the main benefits of using the HHO gas in engines is that it has no carbon content. It also means that carbon-based emissions, primarily $\mathrm{CO}, \mathrm{CO}_{2}$, and soot, can be reduced, with NOx being the only harmful combustion byproduct.

Compared to conventional hydrocarbon fuels, hydrogen has a small quenching distance. Therefore, there is a higher temperature gradient near the combustion chamber wall, resulting in increased combustion heat loss [9]. When using $\mathrm{HHO}$ gas in PFI engine applications, the shorter quenching distance and the high-level flame velocity in the air mean that the possibility of flame flashback entering the intake manifold increases. A modification of the engine's geometry, a reduction in the volume of the void, re-adjustable operating conditions, and total elimination of the discharge or residual power of the ignition system will mitigate this issue [10].

Hydrogen's physical and thermochemical properties may aid in the development of an effective internal combustion engine. When comparing their diffusion coefficients in air, for example, hydrogen diffuses four times faster than CNG. This assists in mixing fuel and air in the ICE's cylinder. Hydrogen displaces about $30 \%$ of the combustion chamber in stoichiometric condition, compared to about $1 \%$ to $2 \%$ of gasoline [44]. The flammability limit of hydrogen in the air (4-76\%) is large, and the flame intensity is high, indicating that $\mathrm{HHO}$ gas will burn lean, increasing thermal efficiency [11]. The adiabatic flame temperature of hydrogen is comparatively high at the stoichiometric ratio, which facilitates NOx formation [12].

Some benefits of the HHO gas economy include energy security by reducing the oil imports [14]. Furthermore, the $\mathrm{HHO}$ gas is a sustainable energy due to advantage of renewable energy sources. It can also reduce pollution and improve urban air quality by producing near-zero carbon, hydrocarbon, GHG, and NOx emissions. In short, the economic viability of HHO gas is potentially shaping the future global markets.

Highly complicated systems and gas production are the biggest obstacles to apply HHO technologies in the actual market. The HHO generation device takes up a lot of space because it needs a power source (battery), an electrolyzer, a bubbler unit, a flash arrestor, and water and electrolyte storage tanks. As a result, using $\mathrm{HHO}$ in cars necessitates significant changes to the current engine system [44]. Currently, the efficiency of the HHO generation of electrolyzers is 40 to $70 \%$. Increases in current density, working pressure, temperature, the conductivity of the electrolyte solution, electrode conditions, and other variables will all contribute to increased performance [48].

Safety issue also becomes the main challenge to fabricate the design. The high diffusivity, wide flammability limits, poor combustion potential, and fast quenching period of hydrogen flames increase the risk of explosion and flashback. In the event of a collision, the HHO gas contained on 
board could efficiently combust, and to protect against these dangers, sturdy storage containers, flashback arresters, and leak detector sensors are needed [49]. In both cases, material science is required to enhance properties and extend life spans. Furthermore, in the same system, hydrogen production and $\mathrm{CO}_{2}$ reaction can coincide [60].

The $\mathrm{HHO}$ gas has great potential to reduce fuel consumption without power loss and reduce emissions in $\mathrm{HC}, \mathrm{CO}, \mathrm{CO}_{2}$, and particulate matter (PM) emissions. $\mathrm{HHO}$ gas production and the comparison of a dry cell and wet cell to produce $\mathrm{HHO}$ gas used as duel fuel in internal combustion engines have been explained in a previous work. This article focuses on different performance reports and the emission characteristics of a compression ignition engine.

Table 1

Properties of hydrogen, Gasoline, Methane, and Diesel $[2,3,5,12]$

\begin{tabular}{llllllll}
\hline Fuel & LHV & HHV & Combustible & Flame & Min. Ignition & Autoignition \\
(MJ/Kg) & $(\mathrm{MJ} / \mathrm{Kg})$ & $\begin{array}{l}\text { Stoichiometric } \\
\text { range (\%) }\end{array}$ & $\begin{array}{l}\text { temp (C) } \\
\text { energy (MJ) }\end{array}$ & $\begin{array}{l}\text { temp (C) } \\
\text { Air/fuel. weight }\end{array}$ \\
\hline Methane & 50.0 & 55.5 & $5-15$ & 1914 & 0.30 & $540-630$ & 17.2 \\
Hydrogen & 119.9 & 141.6 & $4-75$ & 2207 & 0.017 & 585 & 34.3 \\
Gasoline & 44.5 & 47.3 & $1.3-7.1$ & 2307 & 0.29 & $260-460$ & 14.5 \\
Diesel & 42.5 & 44.8 & $0.6-5.5$ & 2327 & - & $180-320$ & 14.7 \\
\hline
\end{tabular}

\section{HHO Generator Configuration}

$\mathrm{HHO}$ generators have several advantages compared to heat engines. These benefits include high performance, near-silent running, and no pollutant emissions if hydrogen is used as fuel [14]. The electrical power generated will be completely sustainable if hydrogen is created using renewable energy sources. HHO generators are classified into two categories based on their system: dry cell and wet cell [15]. The difference between the HHO dry cell and the HHO wet cell is that the wet cell has the whole unit immersed in water, while rubber gaskets isolate the dry cell plates, and the electrolyte flows into them. The electrolyte does not include the plates or electrical contacts. Since they are kept dry, they are referred as dry cells [13]. In the manufacturing of HHO gas, a combination of physical and operational parameters are critical. These parameters will be addressed in detail in the parts that follow. some of the most significant physical parameters for producing $\mathrm{HHO}$ gas are as follows
(a) Material of the electrodes
(b) Arrangement of plates
(c) Number of electrodes and neutral plate
(d) The gap between the electrodes
(e) Cross-section area
(f) Type of electrolyte
(g) Amount of electrolyte

\subsection{Types of Material for Electrode Configuration}

Generally, any conductive material can be used as an electrode. Only a particular electrode is efficient for the electrolysis process to get a better HHO production. Stainless steel is used as an electrode for the researcher in the study, and it is suitable for this use. Therefore, it has a longer lifespan than iron plates and does not form precipitates because no reaction occurs during electrolysis, so no significant chemical reactions occur. Iron is the most abundant and cheapest conductive metal in various shapes and sizes in the market. However, iron plates reduce the generator's life because iron oxidizes in electrolyte, and rust particles are precipitated and 
contaminate the solution in the $\mathrm{HHO}$ cell generator. In addition, among the materials mentioned earlier, copper is highly conductive and corrosive. If copper is used, $\mathrm{H}_{2} \mathrm{SO}_{4}$ should be used as the electrolyte. The electrolyte will be in copper sulfate and may cause blockage of the generator piping system.

Table 2

Types and characteristics of materials $[14,16,18,22,36]$

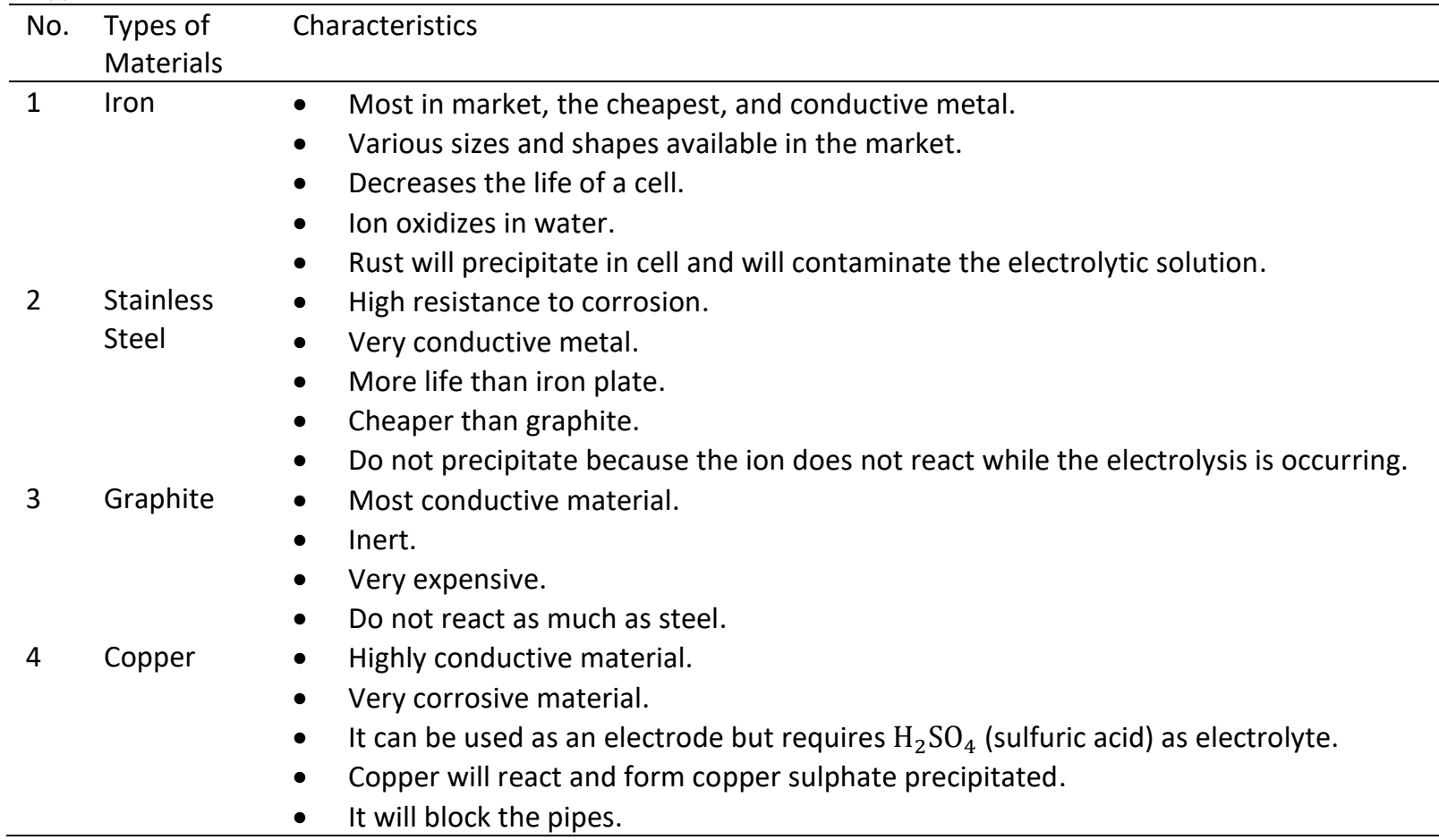

\subsection{Effects of Electrode Configuration on the Production}

Table 3 and Table 4 demonstrate how to configure the plates and optimize the electrolyte concentration for the best HHO gas output. As seen in Table 3, the Cathode plate, Anode plate, and Neutral plate are designated as $\mathrm{C}, \mathrm{A}$, and $\mathrm{N}$, respectively. As the electrolyte concentration increases, the amount of $\mathrm{HHO}$ produced increases. Hence, this results in the increase of conductivity and decrease in resistance [21]. The rise in $\mathrm{HHO}$ gas production is perpendicular to the concentration of the electrolyte. The effective area for the electrolysis process will increase as the number of electrodes increases, accompanied by reaction activity and increasing current density, which will enhance electron transfer between the electrodes, resulting in high water dissociation and improved conductivity. The reviews by Essuman et al., [51] found that increasing the number of neutral plates between the cathode and anode will reduce the system potential. As the neutral plate between the anode and cathode increases, the potential between the stacks decreases [17]. As a result, the potential drop leads to increased temperature, which increases ion mobility, effectively collides, and causes a significant increase in HHO gas production [19]. 
Table 3

Electrodes arrangement

\begin{tabular}{|c|c|c|c|c|}
\hline Design & Arrangement & $\begin{array}{l}\text { Number of } \\
\text { Anode }\end{array}$ & $\begin{array}{l}\text { Number of } \\
\text { Cathode }\end{array}$ & $\begin{array}{l}\text { Number of } \\
\text { Neutral Plates }\end{array}$ \\
\hline & $3 A 3 C$ & 3 & 3 & 0 \\
\hline & $3 A 3 C 2 N$ & 3 & 3 & 2 \\
\hline & $1 \mathrm{~A} 2 \mathrm{C} 8 \mathrm{~N}$ & 1 & 2 & 8 \\
\hline & 7A7C & 7 & 7 & 0 \\
\hline & $7 A 7 C 2 N$ & 7 & 7 & 2 \\
\hline & $7 A 7 C 4 N$ & 7 & 7 & 4 \\
\hline & $5 A 5 C 10 N$ & 5 & 5 & 10 \\
\hline & $5 A 6 C 10 N$ & 5 & 6 & 10 \\
\hline & $10 A 10 C 5 N$ & 10 & 10 & 5 \\
\hline & $3 A 4 C 19 N$ & 3 & 4 & 19 \\
\hline
\end{tabular}

Red $=$ Cathode, Black = Anode, Grey = Neutral plate

Table 4

Effect of Concentration on $\mathrm{HHO}$ gas production [21]

\begin{tabular}{llllll}
\hline No. & Configuration & Current, A & Number of plate & $\begin{array}{l}\text { Volume flowrate } \\
\mathrm{ml} / \mathrm{min}\end{array}$ & $\begin{array}{l}\text { NaOH Concentration } \\
(\%)\end{array}$ \\
\hline 1 & 5C5A10N & 28 & 20 & 510 & 5 \\
2 & 4C3A19N & 7 & 26 & 615 & 5 \\
3 & 3C3A & 9 & 6 & 110 & 10 \\
4 & 7C7A & 25 & 14 & 264 & 10 \\
5 & 6C5A10N & 30 & 21 & 767 & 10 \\
6 & 4C3A19N & 10 & 26 & 675 & 10 \\
7 & 10C10A5N & 48 & 25 & 1025 & 10 \\
8 & 4C3A19N & 15 & 26 & 743 & 15 \\
9 & 3C3A2N & 12 & 8 & 155 & 20 \\
10 & 2C1A8N & 18 & 11 & 230 & 20 \\
12 & 7C7A2N & 23 & 16 & 295 & 20 \\
13 & 7C7A4N & 32 & 18 & 490 & 20 \\
14 & 6C5A10N & 34 & 21 & 820 & 20 \\
15 & 10C10A5N & 60 & 25 & 1250 & 20 \\
\hline
\end{tabular}

\subsection{Spacing between the Electrodes}

Table 5 indicates that the rate of HHO gas production increases as the electrode gap decreases. $\mathrm{HHO}$ performance is influenced by the distance between the anode and the cathode. The resistance is directly proportional to the distance between the electrodes, and the resistance can be minimized by shortening the distance. Therefore, reducing the distance between the electrodes will reduce the resistance, and a minimum distance must be maintained to prevent the gap from rupturing [44]. Meanwhile, according to Nabil and Dawood [37], rubber under pressure has a thickness tolerance of $2 \mathrm{~mm}$. A final thickness of $2 \mathrm{~mm}$ is appropriate to reach the current tolerance and provide enough room for HHO gas to escape freely in the desired direction. Ismail et al., [26] discovers that the operating current in the $\mathrm{HHO}$ generator is significantly smaller than predicted. Because of the high resistance of water, adjusting the electrode spacing is preferred. A generator with a distance of 1.5 
$\mathrm{mm}$ between each plate has a working current of $6 \mathrm{~mm}$, twice the current. Current of $2 \mathrm{~mm}$ is preferable. The gap would decrease the resistance. However, the distance should not be smaller than $2 \mathrm{~mm}$, since the HHO bubbles would not pass across it.

Table 5

Effect of Cross Section Area and Spacing between Electrodes on HHO gas production $[21,44]$

\begin{tabular}{llllll}
\hline $\begin{array}{l}\text { Number of } \\
\text { Plates }\end{array}$ & $\begin{array}{l}\text { Number of } \\
\text { Stacks }\end{array}$ & Gap & $\begin{array}{l}\text { Size of Plate, } \\
\mathrm{mm}^{2}\end{array}$ & $\begin{array}{l}\text { Current, Amp } \\
\text { Flowrate, } \\
\mathrm{ml} / \mathrm{min}\end{array}$ \\
\hline 11 & 2 & 4 & $120 \times 160$ & 6 & 320 \\
13 & 2 & 4 & $140 \times 100$ & 11 & 513 \\
13 & 2 & 2 & $120 \times 120$ & 9 & 470 \\
25 & 4 & 2 & $120 \times 120$ & 18 & 550 \\
14 & 3 & 2.5 & $180 \times 120$ & 15 & 650 \\
14 & 3 & 5 & $180 \times 120$ & 12 & 440 \\
\hline
\end{tabular}

\subsection{Effects of Cross Section Area on HHO Gas Production}

The generation rate of $\mathrm{HHO}$ gas improves by increasing the cross-sectional area of the plate, as seen in Table 5. The reason for this is that the electrode's greater surface area decreases resistance. The electrode diameter increases rather than the height since the latter raises the chance of void fracture [44]. The intensity of current propagated per unit cross-sectional area, measured in amperes per square meter, is known as current density [27]. The higher the current density, the more gas is created. As temperature rises, so does ion mobility and the effective number of collisions. The geometry of the electrode surface can be modified to adjust the expected field of the electrode. The movement of ions in the electrolyte solution is responsible for the production of HHO gas. The electrode's shape will amend the effective area or surface, increasing gas production efficiency [5]. In addition, hydrogen and oxygen need to be formed on the effective surface of the electrode. As a result, a large amount of gas accumulation caused by the active electrode surface is produced [51]. Finally, when the active electrode is placed in a vertical position, the efficiency of gas generation will also be high due to the decrease in ohmic resistance caused by the "optimal bubble leaving rate" [53]. The perforated electrode with a particular porosity significantly impacts the generator's overvoltage and bubble separation frequency.

\subsection{Effects of Electrolyte on the HHO Gas Production}

The electrolytic solution is the solution that induces conduction. There should be solvents and solutes to form a solution. Since hydrogen needs to be extracted from water, water is used as solvent. Impurities in ordinary water can limit effectiveness, so deionized or distilled water should be used. Some salt, anything that can carry free electrons into the water, can be used as solute. Selecting solute chemicals should be done with caution since it can significantly impact the HHO generator's performance and safety.

The variation of the electrolyte is shown in Table 6, and it can be verified that the higher the alkali concentration, the greater the amount of hydrogen produced. In addition, it increases the conductivity and reaction rate of water dissociation compared to the electrolyte in pure water. The electrode ions of hydrogen have a higher potential than $\mathrm{Na}+$ cations. Hydroxides compete for electrons (oxidation) with anion electrolyte during the electrolysis process [20]. Anions have a lower potential electrode compared to hydroxide ions. 
For example, an increase in $\mathrm{NaOH}$ concentration induces an increase in $\mathrm{HHO}$ gas due to more $\mathrm{OH}$ and $\mathrm{Na}+$ ions and increased conductivity [23]. Tap water decreases current use and HHO flow due to the rise in resistance [21]. According to El Kady et al., [21], increased $\mathrm{KOH}$ concentration induces conductivity to increase, resistance to decrease, and HHO flow to increase. Porciúncula et al., [52] compares results from $\mathrm{KOH}$ and $\mathrm{NaOH}$ solutions and discovers that the chemical reaction moves faster in the presence of $\mathrm{KOH}$. This could mean that each base's catalytic mechanism is slightly different, but this is reinforced by the fact that the activation energy of each experiment is higher in the presence of $\mathrm{KOH}$. As a result, corrosion activation energy is proportional to the current transfer density. Corrosion reactions are less likely to occur when the activation energy is more remarkable.

\section{Table 6}

Effects of electrolyte types on HHO production [21,25,42]

\begin{tabular}{lllll}
\hline Number of Plates & Configuration & Electrolyte & Amperage, A & Flowrate, $\mathrm{ml} / \mathrm{min}$ \\
\hline 20 & $8 \mathrm{~A} 8 \mathrm{C} 4 \mathrm{~N}$ & Tap water & 10 & 180 \\
20 & $10 \mathrm{~A} 10 \mathrm{C}$ & Tap water & 13 & 150 \\
20 & $8 \mathrm{~A} 8 \mathrm{C} 4 \mathrm{~N}$ & $1 \mathrm{~g} \mathrm{NaOH}$ & 12 & 219 \\
20 & $10 \mathrm{~A} 10 \mathrm{C}$ & $1 \mathrm{~g} \mathrm{NaOH}$ & 18 & 190 \\
20 & $8 \mathrm{~A} 8 \mathrm{C} 4 \mathrm{~N}$ & $1 \mathrm{~g} \mathrm{KOH}$ & 16 & 230 \\
20 & $10 \mathrm{~A} 10 \mathrm{C}$ & $1 \mathrm{~g} \mathrm{KOH}$ & 20 & 255 \\
\hline
\end{tabular}

\subsection{Dry cell and Wet cell}

According to previous researches, the comparison of dry and wet cells of $\mathrm{HHO}$ generators can be summarized as follows [10]

Table 7

Differences between dry cell and wet cell

\begin{tabular}{ll}
\hline Dry Cell & Wet Cell \\
\hline Require less electrolytes & Require more electrolytes \\
Light & Heavy \\
Less space consumption & More space consumption \\
The electrical connection is safe because & The electrical connection is easy to destroy \\
the wire does not have contact with the & because it is immersed in the electrolyte \\
electrolyte & \\
Plate material has extended lifetime & Plate material has shorter lifetime \\
\hline
\end{tabular}

Wet cell and dry cell HHO generators are two different $\mathrm{HHO}$ generators that can produce $\mathrm{HHO}$ gas. The electrodes in a wet cell are immersed in the electrolyte and located in a water container. Wet cells have a range of benefits, including increased gas generation, increased flexibility, ease of maintenance, and ease of manufacturing. On the other hand, a wet cell has the limitation of consuming more current, generating more heat, and allowing corrosion to occur through the positive electrode (anode) [37]. The heat provided by the cell and the additional current still generates more heat, turning water to steam, and replacing hydrogen with steam [30].

The design of dry cell overcomes the factors faced by wet cell. As a result, the two types of HHO gas are the same, but the difference depends on the displacement of the electrolyte cell and the electrode plate. Dry HHO batteries have many advantages. For example, each HHO cell requires less current due to the size of the electrolyte in the enclosed room. Its compact design is beneficial to modern engines and reduces the frequency of maintenance. Due to the limited amount of electrolyte per second, there is less corrosion on the anode plate [38]. 


\section{Results}

\subsection{Engine Performance with HHO Gas}

The performances of HHO gas depend on brake power, brake torque, brake specific fuel consumption, and brake thermal efficiency, which are discussed as a subchapter below. The overall engine performance is summarized in Table 8.

\section{Table 8}

Performances of Hydroxyl gas for ICE

\begin{tabular}{|c|c|c|c|c|c|}
\hline $\begin{array}{l}\text { Engine } \\
\text { Type }\end{array}$ & $\begin{array}{l}\text { Brake Power } \\
(\mathrm{kW})\end{array}$ & $\begin{array}{l}\text { Brake Torque } \\
(\mathrm{Nm})\end{array}$ & $\begin{array}{l}\text { Brake Specific fuel } \\
\text { consumption } \\
\text { (Kg/KWhr) }\end{array}$ & $\begin{array}{l}\text { Brake Thermal } \\
\text { Efficiency (\%) }\end{array}$ & Ref \\
\hline $\mathrm{Cl}$ & - & INCREASE & DECREASE & - & $\begin{array}{l}\text { Yilmaz et al., } \\
\text { [12] }\end{array}$ \\
\hline $\mathrm{Cl}$ & INCREASE & - & DECREASE & INCREASE & $\begin{array}{l}\text { Bari and } \\
\text { Esmaeil [22] }\end{array}$ \\
\hline $\mathrm{Cl}$ & INCREASE & INCREASE & DECREASE & - & $\begin{array}{l}\text { Samuel and } \\
\text { McCormick [42] }\end{array}$ \\
\hline $\mathrm{Cl}$ & INCREASE & - & DECREASE & DECREASE & $\begin{array}{l}\text { Birtas and } \\
\text { Chiriac [23] }\end{array}$ \\
\hline $\mathrm{Cl}$ & - & INCREASE & DECREASE & INCREASE & Shasikant et al., [45] \\
\hline $\mathrm{Cl}$ & INCREASE & INCREASE & DECREASE & INCREASE & Arat et al., [46] \\
\hline $\mathrm{Cl}$ & INCREASE & INCREASE & DECREASE & INCREASE & Durairaja et al., [26] \\
\hline $\mathrm{Cl}$ & INCREASE & - & DECREASE & - & Masjuki et al., [35] \\
\hline $\mathrm{Cl}$ & INCREASE & INCREASE & DECREASE & - & $\begin{array}{l}\text { Baltacioglu } \\
\text { et al., [4] }\end{array}$ \\
\hline $\mathrm{Cl}$ & INCREASE & - & - & INCREASE & Karagöz et al., [28] \\
\hline $\mathrm{Cl}$ & - & INCREASE & DECREASE & INCREASE & El-Kassaby et al., [27] \\
\hline $\mathrm{Cl}$ & INCREASE & INCREASE & DECREASE & INCREASE & Ozcanli et al., [47] \\
\hline $\mathrm{Cl}$ & INCREASE & - & - & INCREASE & Saravanan et al., [9] \\
\hline $\mathrm{Cl}$ & INCREASE & DECREASE & DECREASE & - & $\begin{array}{l}\text { Rimkus et al., } \\
\text { [41] }\end{array}$ \\
\hline $\mathrm{Cl}$ & - & INCREASE & DECREASE & INCREASE & $\begin{array}{l}\text { Kale and Dahake } \\
\text { [31] }\end{array}$ \\
\hline $\mathrm{Cl}$ & INCREASE & INCREASE & DECREASE & INCREASE & Ozgur et al., [39] \\
\hline $\mathrm{Cl}$ & INCREASE & - & DECREASE & - & Zammit et al., [50] \\
\hline $\mathrm{Cl}$ & - & INCREASE & DECREASE & INCREASE & Arat et al., [46] \\
\hline $\mathrm{Cl}$ & INCREASE & INCREASE & DECREASE & - & $\begin{array}{l}\text { Kale and Dahake } \\
\text { [31] }\end{array}$ \\
\hline
\end{tabular}

\subsubsection{Brake Power (BP)}

Brake power is the power generated by the engine on the output shaft. The piston connecting rod and the crank will transfer the specified power produced in the internal combustion engine's cylinder. As a result of friction between the engine's moving parts, some of the indicated power produced within the cylinder will be lost. The difference between the indicated power generated in the engine cylinder and the energy lost due to friction would be proportional to the net power available at the crankshaft. The greater the braking load on the dynamometer, the greater the torque produced [1]. Table 8 shows that the brake power increases when HHO gas is introduced in the combustion chamber. The improvement in brake power happens because when a mixture of oxyhydrogen gas and diesel is burned, more energy is emitted than when only diesel is burned [45]. Since hydrogen has a high calorific value, it can aid in pure combustion of fuel, resulting in cleaner 
combustion [49]. Because of the high oxidation heat of hydrogen, the increase in braking efficiency in the presence of $\mathrm{HHO}$ is attributed to improved combustion [35]. Apart from that, Shitole et al., [55] reported that using $\mathrm{HHO}$ gas enriched diesel fuel in an internal combustion engine improves engine efficiency by $6 \%$ and increases indicated power by $6 \%$ over baseline diesel fuel.

\subsubsection{Brake Torque (BT)}

Table 8 demonstrates how the brake torque output has improved over time. Torque is a measure of the working ability of an engine to overcome obstacles or increase engine speed [1]. The rise in strength induced by the addition of $\mathrm{HHO}$ gas is due to the oxygen concentration of $\mathrm{HHO}$ gas and better mixing of $\mathrm{HHO}$ with air and fuel, resulting in improved combustion [12]. Compared to traditional liquid fuels, hydrogen has a higher heating value and flame velocity [5]. On the other hand, the high-level HO gas flame speed reduces the ignition delay. It shortens the combustion time, thereby reducing the heat loss closer to the ideal constant volume combustion and improving the compression ratio and thermal efficiency. According to Sudarmanta et al., [1], the braking torque increases as the engine speed increases until it reaches $3000-3500 \mathrm{rpm}$, and tends to decrease as the engine speed increases. This is due to the turbulence generated in the combustion chamber, which becomes higher as the engine speed increases, thereby enhancing the mixing of air and fuel and the spread of fire. $\mathrm{HHO}$ has a high flame speed and a wide range of flammability, which helps to burn energy faster and more entirely under constant speed condition [6].

\subsubsection{Brake Specific Fuel Consumption (BSFC)}

Brake specific fuel consumption (BSFC) is a measure that compares ICE efficiency with shaft output. The BSFC of hydrogen-rich fuel is smaller than pure diesel. The definition of BSFC is unambiguous; that is, the equivalent fuel energy required to generate braking power for all fuel BSFCs initially decreases with the injection pressure and increases with the injection pressure. BSFC can be enhanced by increasing fuel usage or reducing engine performance [9]. The changes in BSFC performance are shown in Table 8. This table shows that when the hydroxyl gas is enriched, the specific fuel consumption decreases. The reduction of BSFC is attributed to the homogeneous mixing of HHO gas with air (high diffusivity of oxygen) and oxygen. HHO gas assists diesel fuel in the combustion process and produces better combustion [40]. HHO is proficient in fuel design; hydrogen and its oxygen exist in small groups, close to two particles in each combustible unit. In addition, the gas is composed of a large number of broad hydrocarbon atoms. The diatomic design of $\mathrm{HHO}$ gas $\left(\mathrm{H}_{2}\right.$, $\mathrm{O}_{2}$ ) can be fully combusted. The reason is that hydrogen and oxygen particles react quickly without initial diffusion delay because of the response surface propagation time. In the beginning, its fire front flashes through the combustion chamber at a higher speed than the standard gas/air ignition [18]. With the additional fuel drawn in the engine, less diesel fuel is injected, and the heat released during the mixing control phase is also reduced [23].

\subsubsection{Break Thermal Efficiency (BTE)}

The ratio of usable power available on the engine crankshaft to the input energy given to the engine in the form of chemical energy available in the fuel is known as BTE [10]. The improvements in braking thermal efficiency after applying the HHO mixture are as seen in Table 8. From the figure, regardless of the load level, the intake percentage of the HHO mixture increases because the flame speed of hydrogen is nine times faster than diesel, thus, the thermal efficiency of the engine's rupture 
improves [22]. As a result, burning diesel in the presence of hydrogen produces complete and rapid combustion [34]. Thus, the peak pressure becomes tremendous, closer to the TDC, and the sufficient pressure increases.

High heating value of hydrogen contained in the gas mixture, high flame velocity, and atomic hydrogen and oxygen are all factors that contribute to the increased efficiency. The improved mixing of hydroxyl gas with air, which leads to better combustion, is responsible for higher thermal efficiency [7]. But Birtas and Chiriac [23] puts forward a different conclusion, that is, the performance of BTE decreases due to the decrease of brake mean effective pressure (BMEP). Another reason for reducing thermal braking efficiency may be improper combustion caused by early injection timing [8]. Hence, this will potentially improve the BTE.

\subsection{Engine Emission with HHO Gas}

The measured $\mathrm{HHO}$ gas emissions depend on $\mathrm{CO}, \mathrm{CO}_{2}, \mathrm{HC}$, and $\mathrm{NO}$ as described in the following subsections, while the summary of emission results is tabulated in Table 9.

Table 9

Emission of hydroxyl gas for ICE

\begin{tabular}{|c|c|c|c|c|c|c|}
\hline Engine Type & $\mathrm{CO}$ & $\mathrm{CO}_{2}$ & $\mathrm{HC}$ & NOx & Smoke & Ref \\
\hline $\mathrm{Cl}$ & DECREASE & - & DECREASE & - & - & $\begin{array}{l}\text { Yilmaz et al., } \\
\text { [12] }\end{array}$ \\
\hline $\mathrm{Cl}$ & DECREASE & INCREASE & DECREASE & INCREASE & - & $\begin{array}{l}\text { Ismail et al., } \\
\text { [18] }\end{array}$ \\
\hline $\mathrm{Cl}$ & DECREASE & DECREASE & INCREASE & INCREASE & INCREASE & $\begin{array}{l}\text { Samuel and } \\
\text { McCormick } \\
\text { [42] }\end{array}$ \\
\hline $\mathrm{Cl}$ & DECREASE & INCREASE & - & INCREASE & DECREASE & $\begin{array}{l}\text { Birtas And } \\
\text { Chiriac [23] }\end{array}$ \\
\hline $\mathrm{Cl}$ & DECREASE & INCREASE & DECREASE & DECREASE & - & $\begin{array}{l}\text { Le Anh et al., } \\
\text { [56] }\end{array}$ \\
\hline $\mathrm{Cl}$ & DECREASE & - & DECREASE & INCREASE & - & $\begin{array}{l}\text { Masjuki et al., } \\
\text { [35] }\end{array}$ \\
\hline $\mathrm{Cl}$ & DECREASE & INCREASE & DECREASE & INCREASE & - & $\begin{array}{l}\text { Baltacioglu } \\
\text { et al., [4] }\end{array}$ \\
\hline $\mathrm{Cl}$ & DECREASE & INCREASE & DECREASE & - & DECREASE & $\begin{array}{l}\text { Karagöz et } \\
\text { al., [32] }\end{array}$ \\
\hline $\mathrm{Cl}$ & DECREASE & INCREASE & DECREASE & INCREASE & - & $\begin{array}{l}\text { Aydin and } \\
\text { Kenanoğlu [3] }\end{array}$ \\
\hline $\mathrm{Cl}$ & DECREASE & - & DECREASE & - & - & $\begin{array}{l}\text { Yilmaz et al., } \\
\text { [12] }\end{array}$ \\
\hline $\mathrm{Cl}$ & DECREASE & - & DECREASE & - & - & $\begin{array}{l}\text { Nabil and } \\
\text { Dawood [37] }\end{array}$ \\
\hline $\mathrm{Cl}$ & DECREASE & INCREASE & - & INCREASE & - & $\begin{array}{l}\text { Arat et al., } \\
{[46]}\end{array}$ \\
\hline $\mathrm{Cl}$ & DECREASE & - & DECREASE & INCREASE & DECREASE & $\begin{array}{l}\text { Kale and } \\
\text { Dahake [31] }\end{array}$ \\
\hline $\mathrm{Cl}$ & DECREASE & - & DECREASE & INCREASE & DECREASE & $\begin{array}{l}\text { Bari and } \\
\text { Esmaeil [24] }\end{array}$ \\
\hline $\mathrm{Cl}$ & DECREASE & INCREASE & DECREASE & INCREASE & - & $\begin{array}{l}\text { Zammit et al., } \\
\text { [50] }\end{array}$ \\
\hline $\mathrm{Cl}$ & - & - & DECREASE & INCREASE & DECREASE & $\begin{array}{l}\text { Saravanan et } \\
\text { al., [9] }\end{array}$ \\
\hline
\end{tabular}




\subsubsection{Carbon monoxide (CO)}

Carbon monoxide emissions are affected by engine combustion efficiency and air-fuel ratio. Therefore, as shown in Table 9, the use of HHO gas with internal oxygen content can enrich the engine's combustion process and reduce the percentage of $\mathrm{CO}$ in the exhaust gas. It can be explained by lower carbon ratios and higher $\mathrm{O}_{2}$ concentrations in $\mathrm{HHO}$ gas [36]. Oxygen aids carbon oxidation and raises the mixture's concentrations in biodiesel $[38,47]$. The diatomic and molecular bonds in the atomic structure of $\mathrm{HHO}$ gas, along with a quick start time and no ignition propagation delay due to reaction surface travel time, ensure maximum and efficient fuel combustion and lower emission percentages [39]. The lack of carbon in hydrogen fuel and the lean mixture (high air-fuel ratio) account for this [29]. Thus, the $\mathrm{CO}$ emissions have the potential to reduce the emission when introducing to $\mathrm{HHO}$ gas.

\subsubsection{Carbon dioxide $\left(\mathrm{CO}_{2}\right)$}

The variation of the $\mathrm{CO}_{2}$ increases compared to diesel engines in Table 9. As expected, a decrease in $\mathrm{HC}$ oxidation results in increased $\mathrm{CO}_{2}$ emissions [50]. $\mathrm{CO}_{2}$ emissions are rising because hydrogen has higher diffusing property. Because of its high flame velocity, $\mathrm{OEH}-\mathrm{HHO}$ gas makes the fuel mixture more homogeneous, resulting in more $\mathrm{CO}_{2}$ emission when combustion starts to initiate. Furthermore, it depends on the increase of $\mathrm{H} / \mathrm{C}$ rate in total fuel with hydrogen addition, the combustion duration is shortened, and the combustion efficiency is improved [54]. Rajaram et al., [10] study the effects of adding oxygen-enriched $\mathrm{HHO}$ gas to direct injection diesel engines' efficiency, emissions, and combustion characteristics. The $\mathrm{CO}_{2}$ emissions are higher if combustion is successful. Higher combustion efficiency is obtained due to the catalytic activity of $\mathrm{HHO}$ gas on combustion that increases $\mathrm{CO}_{2}$ emissions. On the other hand, high concentrations of oxygen and hydrogen in $\mathrm{HHO}$ gas boost the combustion process, which is thought to be the primary factor for the decrease of $\mathrm{CO}_{2}$ emissions due to $\mathrm{HHO}$ addition [42]. Therefore, substituting or adding the HHO into the ICE will significantly improve combustion, which results in a complete combustion.

\subsubsection{Hydrocarbon}

The formation of $\mathrm{HC}$ emissions is potentially reduced as the concentration of $\mathrm{HHO}$ gas increases with the compression ratio, as shown in Table 9. In both operational modes, the $\mathrm{HC}$ level in the combustion products is lower when the engine runs on $\mathrm{HHO}$ petrol than when it runs on diesel fuel. Since the oxygen content in the medium is higher, the hydroxyl gas's hydrocarbons have a more significant combustion effect [5]. The lack of carbon in hydrogen fuel and improved combustion of diesel fuel with the aid of hydrogen, with a faster flame speed, has resulted in a decrease in HC emissions [19]. According to Nabil and Dawood [38], the HC decreases as the engine speed increases. The engines with integrated $\mathrm{HHO}$ gas with air and fuel mixture also have lower $\mathrm{HC}$ concentrations than standard engines. Since oxygen is already present in a sensible proportion in $\mathrm{HHO}$ gas, $\mathrm{HC}$ is also reduced due to increased fuel oxidation, resulting in shorter quenching distances, a wide range of flammability, and high combustion efficiency. Due to the above reasons, the $\mathrm{HC}$ emissions tend to be reduced once the $\mathrm{HHO}$ is added to the ICE, especially diesel engines. 


\subsubsection{Nitrogen oxide (NOx)}

NOx is generated during the combustion process due to three factors: high temperature, oxygen concentration, and residence time. If these three factors are present in the combustion chamber, the deposition of NOx is increased [4]. The gas pressure in the cylinder will rise as the compression ratio rises. The temperature increases as a result. As $\mathrm{HHO}$ is integrated into the fuel supply system, NOx emissions increase. It is discovered that enriching $\mathrm{HHO}$ gas, which has a higher calorific value than diesel, produces a rise in temperature in the combustion chamber, increasing NOx emission [31]. A more effective combustion mechanism (catalyzed by hydrogen) should also be used to reduce the concentration of nitrogen oxides to reduce the free oxygen content in the combustible mixture [47]. However, due to high hydrogen concentration in the combustible mixture, the increase in NOx concentration with $\mathrm{HHO}$ gas is only observed under low load conditions [42]. It is commonly observed that the increase in temperature will slightly increase the NOx emissions.

\subsubsection{Smoke}

The opacity of the smoke significantly decreases as HHO gas is added into the combustion process. Insufficient combustion of the fuel-air mixture causes smoke to be emitted from the engine. As it is introduced into the combustion process, the flue gas can be greatly reduced. Carbonaceous materials formed by combustion make up diesel engine particles, and they absorb certain organic compounds. Most particles are caused by incomplete combustion of hydrocarbon fuels, with lubricating oil playing a minor role. Since hydrogen has no carbon, it emits less particulate matter [43]. Due to the low adiabatic temperature in the combustion chamber with low hydrogen concentration, the increase of flue gas during the combustion phase is regular. At such a low hydrogen fuel content, the fuel mixture product's local temperature decides how much the hydrogen-air mixture burns [10].

\section{Conclusion}

Latterly, the properties and applications of $\mathrm{HHO}$ gas have been discussed, emphasizing its potential as a viable and sustainable alternative fuel. Electrolysis produces $\mathrm{HHO}$ gas at various rates depending on various variables, including electrode material, geometric parameters, type of electrolyte, the concentration of electrolyte, and volume of current transferred. In conclusion, due to the nature of hydrogen in the $\mathrm{HHO}$ gas, the enrichment of the $\mathrm{HHO}$ gas in the internal combustion engine leads to an increase in the engine's braking torque and braking power. A rise in brake thermal efficiency can be seen in many of these situations. The existence of hydrogen in HHO gas, which has a significantly higher heating capacity than fossil fuels, describes this. The fuel consumption per unit of the engine is net reduced. When HHO gas is added, the fuel's burning power increases significantly. This is attributed to the fact that the combined effects of hydrogen and oxygen assist in complete combustion. However, emission characteristics have been improved, resulting in lower $\mathrm{HC}$ and $\mathrm{CO}$ emissions. The HHO gas's higher oxygen capacity would enhance combustion efficiency, resulting in higher NOx emissions.

\section{Acknowledgement}

The authors would like to thank the Ministry of Education Malaysia for partly supporting this research under the Fundamental Research Grant Scheme (FRGS) Vot No. K052 in University Tun Hussein Onn Malaysia. 


\section{References}

[1] Sudarmanta, Bambang, Sudjud Darsopuspito, and Djoko Sungkono. "Application of dry cell HHO gas generator with pulse width modulation on sinjai spark ignition engine performance." International Journal of Research in Engineering and Technology 5, no. 2 (2016): 105-112. https://doi.org/10.15623/ijret.2016.0502019

[2] Arjun, T. B., K. P. Atul, Ajay P. Muraleedharan, P. Albin Walton, P. B. Bijinraj, and A. Arun Raj. "A review on analysis of HHO gas in IC engines." Materials Today: Proceedings 11 (2019): 1117-1129. https://doi.org/10.1016/j.matpr.2018.12.046

[3] Aydin, Kadir, and Raif Kenanoğlu. "Effects of hydrogenation of fossil fuels with hydrogen and hydroxy gas on performance and emissions of internal combustion engines." International Journal of Hydrogen Energy 43, no. 30 (2018): 14047-14058. https://doi.org/10.1016/i.ijhydene.2018.04.026

[4] Baltacioglu, Mustafa Kaan, Hüseyin Turan Arat, Mustafa Özcanli, and Kadir Aydin. "Experimental comparison of pure hydrogen and HHO (hydroxy) enriched biodiesel (B10) fuel in a commercial diesel engine." International Journal of Hydrogen Energy 41, no. 19 (2016): 8347-8353. https://doi.org/10.1016/i.ijhydene.2015.11.185

[5] Baltacıoğlu, Mustafa Kaan. "A novel application of pulse width modulation technique on hydroxy gas production." International Journal of Hydrogen Energy 44, no. 20 (2019): 9726-9734. https://doi.org/10.1016/i.ijhydene.2018.10.228

[6] Carmo, Marcelo, David L. Fritz, Jürgen Mergel, and Detlef Stolten. "A comprehensive review on PEM water electrolysis." International Journal of Hydrogen Energy 38, no. 12 (2013): 4901-4934. https://doi.org/10.1016/j.ijhydene.2013.01.151

[7] Dincer, Ibrahim. "Green methods for hydrogen production." International Journal of Hydrogen Energy 37, no. 2 (2012): 1954-1971. https://doi.org/10.1016/j.ijhydene.2011.03.173

[8] Momirlan, Magdalena, and T. N. Veziroglu. "Current status of hydrogen energy." Renewable and Sustainable Energy Reviews 6, no. 1-2 (2002): 141-179. https://doi.org/10.1016/S1364-0321(02)00004-7

[9] Saravanan, N., G. Nagarajan, C. Dhanasekaran, and K. M. Kalaiselvan. "Experimental investigation of hydrogen port fuel injection in DI diesel engine." International Journal of Hydrogen Energy 32, no. 16 (2007): 4071-4080. https://doi.org/10.1016/i.ijhydene.2007.03.036

[10] Rajaram, Premkartikkumar Selvi, Annamalai Kandasamy, and Pradeepkumar Arokiasamy Remigious. "Effectiveness of oxygen enriched hydrogen-hho gas addition on direct injection diesel engine performance, emission and combustion characteristics." Thermal Science 18, no. 1 (2014): 259-268. https://doi.org/10.2298/TSCI121014078P

[11] Szwaja, Stanislaw, and Karol Grab-Rogalinski. "Hydrogen combustion in a compression ignition diesel engine." International Journal of Hydrogen Energy 34, no. 10 (2009): 4413-4421. https://doi.org/10.1016/i.ijhydene.2009.03.020

[12] Yilmaz, Ali Can, Erinç Uludamar, and Kadir Aydin. "Effect of hydroxy (HHO) gas addition on performance and exhaust emissions in compression ignition engines." International Journal of Hydrogen Energy 35, no. 20 (2010): 1136611372. https://doi.org/10.1016/i.ijhydene.2010.07.040

[13] Zoulias, Emmanuel, Elli Varkaraki, Nicolaos Lymberopoulos, Christodoulos N. Christodoulou, and George N. Karagiorgis. "A review on water electrolysis." TCIST 4, no. 2 (2004): 41-71.

[14] Acar, Canan, and Ibrahim Dincer. "Comparative assessment of hydrogen production methods from renewable and non-renewable sources." International Journal of Hydrogen Energy 39, no. 1 (2014): 1-12. https://doi.org/10.1016/j.ijhydene.2013.10.060

[15] Conker, Çağlar. "A novel fuzzy logic based safe operation oriented control technique for driving HHO dry cell systems based on PWM duty cycle." International Journal of Hydrogen Energy 44, no. 20 (2019): 9718-9725. https://doi.org/10.1016/i.ijhydene.2018.10.243

[16] Conte, Enrico, and Konstantinos Boulouchos. "Influence of hydrogen-rich-gas addition on combustion, pollutant formation and efficiency of an IC-SI engine." SAE Transactions (2004): 611-627. https://doi.org/10.4271/2004-01$\underline{0972}$

[17] Sudrajat, Ajat, Eva Mayfa Handayani, Noreffendy Tamaldin, and Ahmad Kamal Mat Yamin. "Principle of generator HHO hybrid multistack type production technologies to increase HHO gas volume." In SHS Web of Conferences, vol. 49, p. 02016. EDP Sciences, 2018. https://doi.org/10.1051/shsconf/20184902016

[18] Ismail, Tamer M., Khaled Ramzy, M. N. Abelwhab, Basem E. Elnaghi, M. Abd El-Salam, and M. I. Ismail. "Performance of hybrid compression ignition engine using hydroxy (HHO) from dry cell." Energy Conversion and Management 155 (2018): 287-300. https://doi.org/10.1016/i.enconman.2017.10.076

[19] Jakliński, Piotr, and Jacek Czarnigowski. "An experimental investigation of the impact of added HHO gas on automotive emissions under idle conditions." International Journal of Hydrogen Energy 45, no. 23 (2020): 1311913128. https://doi.org/10.1016/i.ijhydene.2020.02.225 
[20] Samuel, Stephen, and Gregory McCormick. Hydrogen enriched diesel combustion. No. 2010-01-2190. SAE Technical Paper, 2010. https://doi.org/10.4271/2010-01-2190

[21] El Kady, M. A., Ahmed El Fatih Farrag, M. S. Gad, A. K. El Soly, and HM Abu Hashish. "Parametric study and experimental investigation of hydroxy (HHO) production using dry cell." Fuel 282 (2020): 118825. https://doi.org/10.1016/j.fuel.2020.118825

[22] Bari, Saiful, and M. Mohammad Esmaeil. "Effect of $\mathrm{H}_{2} / \mathrm{O}_{2}$ addition in increasing the thermal efficiency of a diesel engine." Fuel 89, no. 2 (2010): 378-383. https://doi.org/10.1016/i.fuel.2009.08.030

[23] Birtas, Adrian, and Radu Chiriac. "A study of injection timing for a diesel engine operating with gasoil and HRG gas." UPB Scientific Bulletin, Series D: Mechanical Engineering 73, no. 4 (2011): 65-78.

[24] Birtas, Adrian, Iulian Voicu, Cristian Petcu, Radu Chiriac, and Nicolae Apostolescu. Effects of air-hydrogen induction on performance and combustion of a diesel engine. No. 2011-24-0094. SAE Technical Paper, 2011. https://doi.org/10.4271/2011-24-0094

[25] Chaiwongsa, Praitoon, Nithiroth Pornsuwancharoen, and Preecha P. Yupapin. "Effective hydrogen generator testing for on-site small engine." Physics Procedia 2, no. 1 (2009): 93-100. https://doi.org/10.1016/i.phpro.2009.06.015

[26] Durairaja, R. B., J. Shanker, and M. Sivasankar. "HHO gas with bio diesel as a dual fuel with air preheating technology." Procedia Engineering 38 (2012): 1112-1119. https://doi.org/10.1016/j.proeng.2012.06.140

[27] El-Kassaby, Mohamed M., Yehia A. Eldrainy, Mohamed E. Khidr, and Kareem I. Khidr. "Effect of hydroxy (HHO) gas addition on gasoline engine performance and emissions." Alexandria Engineering Journal 55, no. 1 (2016): $243-251$. https://doi.org/10.1016/j.aej.2015.10.016

[28] Elgarhi, Ibrahim, Mohamed M. El-Kassaby, and Yehia A. Eldrainy. "Enhancing compression ignition engine performance using biodiesel/diesel blends and HHO gas." International Journal of Hydrogen Energy 45, no. 46 (2020): 25409-25425. https://doi.org/10.1016/i.ijhydene.2020.06.273

[29] Gad, M. S., M. K. El-Fakharany, and E. A. Elsharkawy. "Effect of HHO gas enrichment on performance and emissions of a diesel engine fueled by biodiesel blend with kerosene additive." Fuel 280 (2020): 118632. https://doi.org/10.1016/i.fuel.2020.118632

[30] Ismail, Tamer M., Khaled Ramzy, M. N. Abelwhab, Basem E. Elnaghi, M. Abd El-Salam, and M. I. Ismail. "Performance of hybrid compression ignition engine using hydroxy (HHO) from dry cell." Energy Conversion and Management 155 (2018): 287-300. https://doi.org/10.1016/i.enconman.2017.10.076

[31] Kale, K. A., and M. R. Dahake. "The effect of HHO and biodiesel blends on performance and emission of diesel engine - A review." International Journal of Current Engineering and Technology 5, no. 5 (2016): 1-9.

[32] Karagöz, Yasin, Tarkan Sandalcı, Levent Yüksek, Ahmet Selim Dalkılıç, and Somchai Wongwises. "Effect of hydrogendiesel dual-fuel usage on performance, emissions and diesel combustion in diesel engines." Advances in Mechanical Engineering 8, no. 8 (2016): 1-13. https://doi.org/10.1177/1687814016664458

[33] Khan, Naseeb, B. Balunaik, and Syed Yousufuddin. "Performance and emission characteristics of a diesel engine with varying injection pressure and fueled with hydrogen and cottonseed oil methyl ester blends." Materials Today: Proceedings 5, no. 2 (2018): 3369-3377. https://doi.org/10.1016/i.matpr.2017.11.581

[34] Manu, P. V., Anoop Sunil, and S. Jayaraj. "Experimental investigation using an on-board dry cell electrolyzer in a $\mathrm{Cl}$ engine working on dual fuel mode." Energy Procedia $90 \quad$ (2016): 209-216. https://doi.org/10.1016/i.egypro.2016.11.187

[35] Masjuki, H. H., A. M. Ruhul, Nirendra N. Mustafi, M. A. Kalam, M. I. Arbab, and IM Rizwanul Fattah. "Study of production optimization and effect of hydroxyl gas on a $\mathrm{Cl}$ engine performance and emission fueled with biodiesel blends." International Journal of Hydrogen Energy 41, no. 33 (2016): 14519-14528. https://doi.org/10.1016/i.ijhydene.2016.05.273

[36] Krishna, V. Murali, A. Haritha Reddy, M. Sandeep Kumar, and A. Raghu. "Effect of hydroxy gas addition on performance and exhaust emissions in variable compression spark ignition engine." Materials Today: Proceedings 24 (2020): 930-936. https://doi.org/10.1016/i.matpr.2020.04.404

[37] Nabil, Tamer, and Mohamed Khairat Dawood. "Impact of addition oxy-hydrogen gas (HHO) on vehicle engines performance and emissions." Journal of Mechanical and Energy Engineering 3, no. 2 (2019): 177-190. https://doi.org/10.30464/imee.2019.3.2.177

[38] Nabil, Tamer, and Mohamed M. Khairat Dawood. "Enabling efficient use of oxy-hydrogen gas (HHO) in selected engineering applications; transportation and sustainable power generation." Journal of Cleaner Production 237 (2019): 117798. https://doi.org/10.1016/i.jclepro.2019.117798

[39] Ozgur, Tayfun, Erdi Tosun, Ceyla Ozgur, Gökhan Tuccar, and Kadir Aydın. "Numerical studies of engine performance, emission and combustion characteristics of a diesel engine fuelled with hydrogen blends." In Advanced Materials Research, vol. 1016, pp. 582-586. Trans Tech Publications Ltd, 2014. https://doi.org/10.4028/www.scientific.net/AMR.1016.582 
[40] Rashad, Ahmed. "Investigating the effect of oxyhydrogen on the performance of a compression ignition engine." In The International Conference on Applied Mechanics and Mechanical Engineering, vol. 16, no. 16th International Conference on Applied Mechanics and Mechanical Engineering., pp. 1-11. Military Technical College, 2014. https://doi.org/10.21608/amme.2014.35699

[41] Rimkus, Alfredas, Jonas Matijošius, Marijonas Bogdevičius, Ákos Bereczky, and Ádám Török. "An investigation of the efficiency of using $\mathrm{O} 2$ and $\mathrm{H} 2$ (hydrooxile gas-HHO) gas additives in a ci engine operating on diesel fuel and biodiesel." Energy 152 (2018): 640-651. https://doi.org/10.1016/i.energy.2018.03.087

[42] Samuel, Stephen, and Gregory McCormick. Hydrogen enriched diesel combustion. No. 2010-01-2190. SAE Technical Paper, 2010. https://doi.org/10.4271/2010-01-2190

[43] Saravanan, N., and G. Nagarajan. "An experimental investigation of hydrogen-enriched air induction in a diesel engine system." International Journal of Hydrogen Energy 33, no. 6 (2008): 1769-1775. https://doi.org/10.1016/i.ijhydene.2007.12.065

[44] Subramanian, Balaji, and Saleel Ismail. "Production and use of HHO gas in IC engines." International Journal of Hydrogen Energy 43, no. 14 (2018): 7140-7154. https://doi.org/10.1016/j.ijhydene.2018.02.120

[45] Shasikant, Yadav Milind, Suresh M. Sawant, Jayesh A. Anavkar, and Hemant V. Chavan. "Investigations on generation methods for oxy-hydrogen gas, its blending with conventional fuels and effect on the performance of internal combustion engine." Journal of Mechanical Engineering Research 3, no. 9 (2011): 325-332.

[46] Arat, Hüseyin Turan, Mustafa Kaan Baltacioglu, Mustafa Özcanli, and Kadir Aydin. "Effect of using Hydroxy-CNG fuel mixtures in a non-modified diesel engine by substitution of diesel fuel." International Journal of Hydrogen Energy 41, no. 19 (2016): 8354-8363. https://doi.org/10.1016/j.ijhydene.2015.11.183

[47] Ozcanli, Mustafa, Mustafa Atakan Akar, Ahmet Calik, and Hasan Serin. "Using HHO (Hydroxy) and hydrogen enriched castor oil biodiesel in compression ignition engine." International Journal of Hydrogen Energy 42, no. 36 (2017): 23366-23372. https://doi.org/10.1016/i.ijhydene.2017.01.091

[48] Borgschulte, Andreas. "The hydrogen grand challenge." Frontiers in Energy Research 4, no. 11 (2016): 1-8. https://doi.org/10.3389/fenrg.2016.00011

[49] Shitole, Rahul R., Sourabh S. Magdum, Nikhil S. Raut, Sanket Mane, and P. B. Borade. "Performance of Hydroxy Gas on Diesel Engine." International Journal of Advanced Research, Ideas and Innovations in Technology 3, no. 2 (2017): 431-435.

[50] Zammit, Glenn, Mario Farrugia, and Robert Ghirlando. "Experimental investigation of the effects of hydrogen enhanced combustion in SI and Cl engines on performance and emissions." HEFAT 2012 (2012): 641-650.

[51] Essuman, Samuel Pamford Kojo, Andrew Nyamful, Vincent Agbodemegbe, and Seth Kofi Debrah. "Experimental studies of the effect of electrolyte strength, voltage and time on the production of brown's (HHO) gas using oxyhydrogen generator." Open Journal of Energy Efficiency 8, no. 02 (2019): 64. https://doi.org/10.4236/ojee.2019.82005

[52] Porciúncula, C. B., N. R. Marcilio, I. C. Tessaro, and M. Gerchmann. "Production of hydrogen in the reaction between aluminum and water in the presence of $\mathrm{NaOH}$ and $\mathrm{KOH}$." Brazilian Journal of Chemical Engineering 29, no. 2 (2012): 337-348. https://doi.org/10.1590/S0104-66322012000200014

[53] Alam, Noor, and K. M. Pandey. "Experimental study of hydroxy gas (HHO) production with variation in current, voltage and electrolyte concentration." In IOP Conference Series: Materials Science and Engineering, vol. 225, no. 1, p. 012197. IOP Publishing, 2017. https://doi.org/10.1088/1757-899X/225/1/012197

[54] Verhelst, Sebastian, Thomas Wallner, and Roger Sierens. "Hydrogen-Fueled internal combustion engines." In Handbook of Hydrogen Energy, pp. 821-901. CRC Press, 2014.

[55] Shitole, Rahul R., Sourabh S. Magdum, Nikhil S. Raut, Sanket Mane, and P. B. Borade. "Performance of hydroxy gas on diesel engine." International Journal of Advance Research, Ideas and Innovation in Technology 3, no. 2 (2017): 413-435.

[56] Le Anh, Tuan, Khanh Nguyen Duc, Huong Tran Thi Thu, and Tai Cao Van. Improving Performance and Reducing Pollution Emissions of a Carburetor Gasoline Engine by Adding HHO Gas into the Intake Manifold. No. 2013-010104. SAE Technical Paper, 2013. https://doi.org/10.4271/2013-01-0104

[57] Sazali, Norazlianie. "A Short Review on Developing Technologies by Hydrogen." Journal of Advanced Research in Materials Science 59, no. 1 (2019): 14-23.

[58] Sazali, Norazlianie, Mohd Fairusham Ghazali, Haziqatulhanis Ibrahim, Syafikah Huda Paiman, and Mohd Shahrizan Moslan. "A Review on Hydrogen Separation through Inorganic Membranes." Journal of Advanced Research in Fluid Mechanics and Thermal Sciences 63, no. 2 (2019): 238-248.

[59] Basori, Basori. "Experimental investigation ON dry cell HHO generator with catalyst variation for reducing the emissions." Journal of Mechanical Engineering and Vocational Education (JoMEVE) 1, no. 1 (2018): 1-8. https://doi.org/10.20961/jomeve.v1i1.18950 
[60] Kuhl, Kendra P., Etosha R. Cave, David N. Abram, and Thomas F. Jaramillo. "New insights into the electrochemical reduction of carbon dioxide on metallic copper surfaces." Energy \& Environmental Science 5, no. 5 (2012): 70507059. https://doi.org/10.1039/c2ee21234j 